\title{
Multiculturality and interculturality in the educational system
}

\author{
Cornelia Stan
}




\title{
Multiculturality and interculturality in the educational system
}

\author{
Cornelia Stan ${ }^{a^{*}}$ \\ ${ }^{a}$ Faculty of Psychology and Educational Sciences, Babeș-Bolyai University Cluj-Napoca, 7 Sindicatelor Street, 400029, Romania
}

*Corresponding author: cornelia.stan@ubbcluj.ro

\section{Abstract}

\section{Keywords:}

culture; global education; otherness; multicultural educational environment; intercultural competence; cultural values

\section{Zusammenfasung}

\author{
Schlüsselworte: \\ Kultur; globale Bildung; \\ Andersartigkeit; \\ multikulturelles \\ Bildungsumfeld; \\ interkulturelle \\ Kompetenz; kulturelle \\ Werte
}

The structured elaboration of a personal system of values, in line with the culture to which we belong, represents a lasting process, parallel to development, which involves completions and restructurings, adaptations and modifications of the cognitive, attitudinal, affective and axiological system. The conditions of the modern world, oriented towards globalization, no longer allow the isolation of cultures, and the mobility of people creates favorable conditions for the intersection and mutual influence of cultures. For this reason, the development of the capacity to decode cultural meanings and to rationally select multicultural elements that lead to the flexible and creative reorganization of values different from those of the culture of origin, is a desideratum of the education and training of individuals.

\section{Introduction}

The education of the future cannot be separated from the global problems of the world, and any reform in the educational system presupposes the opening of the school towards this theme. In this context, the training and development of young people acquires new meanings and orientations, because school instruction and education, through all the theoretical and practical components must align with current international trends, which aim to create a society open to all cultures. Therefore, such an approach would allow both the maintenance of desirable values of one's own culture and the infusion of positive multicultural influences, capable of causing conscious changes in one's values.

To achieve this goal, changes are needed to target both teachers and students, given that cultivating an education for change is a challenge for anyone. The globalization of political, economic and social life frequently leads to situations in which individuals change their own cultural values, perceptions and judgments, related to personal or educational experiences that involve multicultural interactions. In this context, the objectives of education are aimed at training people to be able to appreciate different cultures coexisting in a multicultural society, agreeing to evolve in contact with these cultures so that diversity becomes a positive element of change, enriching the overall cultural, social and economic life (Sauvé, 2005).

Due to the inherent changes in the contemporary society, the educational field supports permanent adaptations and modifications of its main directions of action. This fact led to the emergence of references to a new concept relevant to modern educational paradigms, this being the concept of global education. This concept aims to 
focus on the educational problems of a world characterized by change, dynamism, independence and pluralism, analyzing the connections of interrelationships, diversity of values, critical thinking, etc. and promotes global and integrated perspectives (Ionescu, 2011).

\section{Multiculturalism and interculturality, culture} and axiology

Culture is not a social reality in itself that can be understood objectively, but presents a multitude of meanings, causalities and points of view. Culture presupposes a certain personal ethics but also an ethic of otherness, and what matters more is the observation and clarification of the relationship with others than the knowledge of cultures. In relation to this approach, intercultural education is considered as a critical transmission of the knowledge of plurality, resulting from interactions and reciprocities. In the current context, pluralism is promoted as a value and purpose of education, as a way of knowing what is universally human or singularity expressed through differences (Latour, 2010).

Due to the increase of the mobility of people, favored by the possibility of free movement in the European space, the Romanian society is more and more open to multicultural and intercultural influences. As in many other countries, new challenges appear for the educational system in Romania in the teacher-student relationship, determined to a significant extent by the increasingly varied cultural characteristics of individuals. In this sense, in the didactic activities it is necessary to reconsider the elements of culture, tradition and spirituality of the students, who are more and more likely to come from diverse multicultural environments. In addition, the intercultural experience of teachers and students can lead to the improvement of the communicative, cognitive and affective-relational dimensions in the educational space, as well as the formation of behavioral skills imposed by cultural diversity.

Although there are sometimes confusions and overlaps of the concepts of multiculturalism and interculturality, the two phrases refer to distinct areas of social reality. While the notion of multiculturalism refers to the interest in promoting differences between different cultures, an interest determined by coexistence in a multiethnic environment in order to facilitate the accommodation of minority ethnocultural groups in a different cultural space, the notion of interculturality involves focusing on relations between different cultures, on the promotion of the values and particularities of each culture designated by a certain race, religion or ethnicity, with the end goal being the creation of bridges across the borders of various cultural areas.

In line with the previous idea, we are increasingly talking about a cultural relativism, which brings into question the limits to which we can talk about the peculiarities of a culture, beyond which we can find cultural similarities. At the same time, cultural relativism requires a certain caution in expressing appreciative or derogatory opinions when we talk about the specifics of a culture, because we must analyze the multitude of differences in all planes of human existence and thought in the context of a particular culture (Nedelcu, 2008).

The opening of borders and the proximity of other cultures have led to the emergence of intercultural dimensions in all sectors of development, including education. Constance Sirois specifies that the purpose of intercultural education is to help individuals identify themselves by taking into account the differences between individuals and communities, to locate these differences in their context, to show their relevance, to explain their importance but also to demonstrate that they are multiple and original expressions of the relationship between oneself and others, as well as between oneself and the universe he populates, representing one of the many facets of his desire for knowledge (Sirois, 1995).

The pattern represented by culture is of great complexity, being structured in a long time and associated with everything that means knowledge, life experiences, values, beliefs, attitudes, conceptual meanings, etc. which supports the establishment of new systems of representations on reality and the approach of new action behaviors in correspondence with them (Jandt, 2018) Educators must take into account that there are certain characteristics specific to each culture, which determine the different valorization of some aspects related to daily life, and these characteristics can be influenced by contact with other cultures. At the same time, cultural influences specific to cultures other than the one of origin may cause definitive, total or partial behavioral changes, especially in young people, but mature enough to make a critical analysis of multicultural values. Given the tendency to migrate in order to complete personal education or provide economic activities, cultural influences are much stronger in terms of profession, education and relationship with the close social group (friends, colleagues, etc.). Observing the axiological changes due to multiculturalism, we can see that they are less obvious in people coming from cultures with a strong and certified tradition, and the adoption of elements foreign to their culture of origin in terms of vision and social behavior is done following a process of critical analysis, freed from the constraints of preconceived ideas (either favorable or unfavorable to a particular culture).

The appeal to the multicultural and intercultural experiences of the young people and to the judicious analysis of the symbolic level of different cultures favors the reorganization of the system of personal values, determining the structuring of intercultural competences. Multiculturalism and interculturality must be taken into account when building a functional and tolerant educational environment, in which interpersonal communication plays an essential role. Since the 1980s, communication has become a major area of interest, frequently associated with the concept of communicative competence, gradually 
adding the notion of transnational communication (a notion first used by Manfred Bock at the Conference of the Association of Modern Foreign Languages, 1982). This term reflects not only the relationship between two foreign languages but also a certain culture of their origin. Basically we cannot separate communication from culture, and in a multicultural environment, communication must be permanently associated with the cultural particularities of the participants in the communication process. Interculturality is based on linguistic interaction because, as E. Sapir has expressed since the beginning of the twentieth century, "language does not exist outside culture, that is, outside the socially inherited system of practices and beliefs that determine the texture of our lives" (Sapir, 1921, p. 100).

In this sense, we must look at intercultural competence in close correlation with communication competence, in a process of learning and cultural and intercultural transformation, through which man can adapt to another culture. However, it also implies the pre-existence or development of communication skills that favor the interaction between individuals, beyond the cultural differences that define them, cognitive elements that lead to a logical, flexible thinking, oriented to axiological elements, valuing information selected from other cultures or a certain intercultural awareness that allows the acceptance of truly precious elements specific to other cultures (Rakotomena, 2005).

Various socio-cultural analyses make attempts to identify the cultural specificity from various corners of the world. One of the analyses that arouses interest in achieving knowledge of cultural specificity is the one developed by L.R. Kohls \& J.M. Knight (Kohls, 2004), who made a list of 13 contrasting values that explain how people are formed, how they assimilate culture and act in correspondence with it. Although this analysis reflects the value system of American culture, the set of 13 cultural values can be appreciated as a guide to any other culture and can be a starting point for any cultural study, making multiple comparisons between the cultural characteristics of different peoples, without necessarily associating them with positive or negative qualities. The respective values are: 1 . Personal control over life versus Responsibility of fate and destiny; 2. Change versus Stability/tradition; 3. Time control/planning versus Time relativity/improvisation; 4. Equality, lack of prejudices versus Inequality/hierarchy, prejudices; 5. Individualism/independence versus Altruism/group wellbeing, dependence; 6 . Activism/ personal initiative versus Passivity/innate/inherited right; 7. Competition versus Cooperation; 8. Orientation towards the future versus Orientation towards the past; 9. Action/work orientation versus Immobility/survival orientation; 10. Informal relations versus formal relations; 11. Frankness, openness/honesty versus Attitude of avoidance/incorrectness; $12 . \quad$ Practical orientation/efficiency versus Theory/inefficiency; 13. Materialism/object acquisitions versus Idealism/expanding relationships with others.

A reflexive training based on the identification of the dominant values of one's own culture and the values characteristic of the representatives of other ethnicities, races, etc. leads to the structuring of intercultural competence, understood as the ability to manifest an open, receptive and flexible attitude in relation to the perspective of other cultures, adopting its specific elements, even if this adaptation requires changing a set of attitudes or behaviors specific to one's own culture.

\section{The relationship between intercultural training - intercultural competence}

In order to achieve intercultural training, we need elements of intercultural education and forms of intercultural learning. The difference between the two concepts mentioned above relates to the main elements that determine the intended changes at the level of individuals. Thus, while intercultural education focuses on educational programs with an emphasis on forming attitudes of tolerance, collaboration, availability for group integration, etc., intercultural learning emphasizes the cognitive elements that lead to a universal intellectual thinking, based on flexibility, on elements of inter-knowledge and exchange of information with those belonging to other cultures.

Although not all those involved in intercultural formation split the two orientations, for a better understanding of how individuals change, it is necessary to make this delimitation. For example, the tendency to focus mainly on the formation of attitudes necessary in intercultural formation, such as tolerance, can lead to a real lack of interaction between groups, with minorities being passively tolerated but not accepted or valued. In the opposite sense, the emphasis on the elements of intercultural learning leads to an excessive rationalization of the elements of knowledge of the specifics of other cultures, but in the absence of awareness of their values and way of life.

Therefore, in intercultural-oriented educational practice, it is necessary for the two orientations to coexist and to establish common specific objectives, such as: clarifying one's own cultural identity; acquiring knowledge regarding the specifics of other cultures; identifying stereotypes, prejudices, etc. present in different cultural spaces; the formation of skills imposed by cultural diversity; formation of positive intergroup attitudes; stimulating participation in various intercultural actions.

In the conception of the pedagogue M. Ionescu, intercultural education develops a pedagogy of interpersonal relationship, helping the student define himself in relation to others. In this way, intercultural training can give a new direction to pedagogy, without replacing the didactic or technical competence of teachers, but complementing it. To achieve such a goal, intercultural 
learning must have the following characteristics: be transversal (applicable to all areas of education); be longitudinal (applicable to all contents of the study disciplines); to be beyond strictly formal learning models, also involving non-formal and informal models); be applicable in all phases of educational programs (design, implementation, monitoring, evaluation); to respect the principles regarding intercultural education, which means that this education respects the student's cultural identity, to provide each student with the cultural knowledge, attitudes and skills necessary for active participation in society, contributing to the development of respect, understanding and tolerance for individuals., ethnicity, groups and nations from a social, cultural or religious point of view (Ionescu, 2011).

The consistent approach of the specific elements of intercultural training favors the development of intercultural competence. Intercultural competence is one of the most necessary competencies of the human individual in modern society. For its formation and development it is advisable to intervene as early as possible, knowing that at the age of childhood and youth, change can be easier.

Intercultural competence (Rakotomena, 2005) is the result of interactions between: 1 . the communicative and the behavioral dimension; 2 . the cognitive dimension and 3. the affective dimension.

At the same time we must look at intercultural competence as a process of cultural and intercultural learning and transformation, through which man can adapt to another culture. In this sense we must support the guidelines of constructivist pedagogy, which promotes the idea that learning does not take place only by confronting students with the point of view of the educator or theories presented in books and textbooks, but by confronting different points of view and different experiences. In this way, the educated person will be able to build his own opinion, as an active subject in the learning process. Programs focused on intercultural training should contribute to the optimization of educational activity in general, balancing the communicative dimension with the cognitive and affective dimensions, in the context of an educational environment characterized by otherness, diversity and multiculturalism. The results obtained could be taken into account in the context of curricular adaptations at all levels of education, in order to achieve approaches focused on intercultural education and intercultural learning. Such a result would facilitate a better social and professional integration, favoring the interactions between the members of the society, in all frames of existence.

Given the influence that intercultural education can have on communication in general and on pedagogical communication in particular, it would be appropriate for it to develop an applicability in all areas of education, both in formal and non-formal education, or informal (Gobel,
2010). The goal would be forming a set of acquisitions that would include cultural knowledge, attitudes, behaviors and competencies that would favor the educational activity as a whole. The development of communication skills on the background of intercultural learning is the core of a good social integration, in any society, even if it has a strong multicultural character. For this reason, ensuring higher mobility in education and training by increasing the supply of programs for teachers or students, focused on exchanges of experience in education systems of other states could play a significant role in enhancing the intercultural nature of instructive-educational activities, with positive effects in general.

To achieve this goal we must discuss the principles of constructivist pedagogy, which brings to the forefront of training not only the ideas and opinions of the educator or various supporters of explanatory theories related to the educational context, but also the concrete experience of the student, in which he forms his own opinions and arguments that prove his ability to learn actively. For this reason, it is appreciated that the experiential intercultural elements can support the efforts to achieve an effective educational process with greater impact. Interaction (especially in formal settings) with everything that involves elements of different cultures can influence the vision of the world, the way of perceiving and understanding those around you, respect for the elements of diversity (Thiéblemont-Dollet, 2003).

\section{Conclusions}

In strict correspondence with the pace of development of society and its overall transformations, it is necessary to take into account another challenging aspect for pedagogy: the realization of an education focused on multicultural and intercultural content. In the 21 st century, the concept of intercultural education is associated with cultural diversity and equal opportunities. Education can no longer be conceived as an activity granted only to the majority groups, to their needs and interests, without an openness towards other cultures or minority groups.

Analyzing this information we can deduce the significance of the concerns of educational systems around the world to introduce in initial and continuous training the issue of intercultural education. By nature, each individual tends to focus on his or her own cultural identity, but this excludes involvement in transformative learning that is equally relevant to others. This is the reason why modern pedagogy militates for the intercultural formation of children / young people and even adults.

In conclusion, intercultural education develops a pedagogy of interpersonal relationships, helping the student define himself in relation to others. Through exercises of reflection and rational analysis of cultural particularities and meanings attributed to various values in different cultures, as well as by promoting analysis and discussion on this topic can ensure communication, intercultural mediation and the formation of intercultural skills, based on 
knowledge, understanding and learning due to intercultural experiences, defined by experiencing difference and otherness (Reynolds-Case, 2013).

Emphasizing the intercultural character of instructiveeducational activities and even expanding intercultural training in adult education could lead to improving the behavioral dimension and the formation of positive intergroup attitudes in the micro or macrosocial space, determining an educational framework based on a good relationship, where respect for each other and the recognition of the cultural values of others is an essential condition for an effective education. The issue of multiculturalism and interculturality remains topical as long as the school of the future acquires an increasingly pronounced multicultural character.

\section{Authors note:}

Cornelia Stan is a lecturer at the Faculty of Psychology and Sciences of Education, at Babeș-Bolyai University Cluj Napoca. Her fields of research and topics of interest are educational communication, interculturality, career counseling, mentoring and coaching in education.

\section{References}

Gobel, K., Helmke, A. (2010). Intercultural Learning in English as Foreign Language Instruction: The Importance of Teachers' Intercultural Experience and the Usefulness of Precise Instructional Directives.Teaching and Teacher Education: An International Journal of Research and Studies, volum $26 \mathrm{nr} 8,1571-1582$.

Ionescu, M. (2011). Instrucţie şi educaţie. Paradigme educaţionale moderne, ediţia a IV-a revizuită şi adăugită. Cluj-Napoca: Editura Eikon.
Jandt, F.E. (2018). An Introduction to Intercultural Communication. Identities in a Global Community. Ninth Edition, Sage Publications, Inc.

Kohls, L.R., Knight, J.M. (2004). Developing Intercultural Awareness: A Cross-Cultural Training Handbook.2nd edition. London: Nicholas Brealey Publishing.

Latour, A. (2010). L'éducation interculturelle: qu'en pensent les enseignants oeuvrant en milieu homogène? Université du Québec à Trois-Rivières.

Nedelcu, A. (2008). Fundamentele educatiei interculturale - Diversitate, minorităţi, echitate. Iaşi: Editura Polirom.

Rakotomena, M.H. (2005). Les ressources individuelles pour la compétence interculturelle individuelle. Revue internationale sur le travail et la société, 3(2) Octobre, 668-691.

Reynolds-Case, A. (2013). The value of short-term study abroad: An increase in students' cultural and pragmatic competency. Foreign Language Annals, 46(2), 311-322.

Sapir, E. (1921). Language: An Introduction to the Study of Speech.New York: Harcourt, Brace and Company.

Sauvé, L. (2005). L'éducation relative à l'environnement et la globalisation: enjeux curriculaires etpédagogiques. Éducation relative à l'environnement: Regards Recherches - Réflexions. Montréal: Chaire de recherche du Canada en éducation relative à l'environnement, Université du Québec à Montréal (UQAM), Vol. 6, 2005, 13-28.

Sirois, C. (1995). L'éducation interculturelle au Saguenay Lac-Saint-Jean selon des responsables des milieux éducatifs: une étude exploratoire. Mémoire de maîtrise inédit, Université du Québec à Chicoutimi.

Thiéblemont-Dollet, S. (2003). Interculturalités. Questions de communication, Numéros 4, 5-11. 